\title{
Actor-Partner Effects of Marital Satisfaction, Happiness and Depression on Parenting Behaviors of Parents with Young Children
}

\author{
Ju Yeong Bae ${ }^{1}$, Hyun-Sim Doh ${ }^{2}$ \\ Visiting Professor, Department of Early-Childhood Education, Gu-mi University, Gu-mi, Korea ${ }^{1}$ \\ Professor, Department of Child Development \& Intervention, Ewha Womans University, Seoul, Korea ${ }^{2}$ \\ 유아기 자녀를 둔 부모의 결혼만족도, 행복감 및 우울감이 \\ 양육행동에 미치는 자기-상대방효과 \\ 배주영 ${ }^{1}$ 도현심 ${ }^{2}$ \\ 구미대학교 유아교육학과 초빙교수 ${ }^{1}$, 이화여자대학교 아동학과 교수 ${ }^{2}$
}

\begin{abstract}
Objectives: This study aimed to examine the actor-partner mediation effects of happiness and depression in relation to marital satisfaction and parenting behaviors.

Methods: The study was conducted on parents with four-year-olds from 1,513 families that participated in the $7^{\text {th }}$ 'Panel Study on Korean Children (PSKC)' by the Korea Institute of Child Care and Education.

Results: Results showed that actor-partner mediation effects of happiness and depression were found in relation to parents' marital satisfaction on parenting behaviors. For actor-partner effects of parents' marital satisfaction on parental warmth and control with happiness as a mediator, there were actor-actor and partner-actor effects. For actor-partner effects of parents' marital satisfaction on parental warmth with depression as a mediator, there were actor-actor effects and partner-actor effects.

Conclusion: The study showed that parents need to establish positive marital relations and make mutual efforts in increasing their happiness and lowering their depression for positive parenting behaviors. Moreover, this research found out that happiness and depression have their own independent characteristics in relation to parents' marital satisfaction and parenting behaviors.
\end{abstract}

Keywords: actor-partner effects, marital satisfaction, happiness, depression, parenting behaviors

\section{Introduction}

부모의 양육행동은 아동의 일생 전반에 걸쳐 영향을 미치는 중요한 요인으로 아동의 모든 발달 영역에 결정적인 영향을 미친다. 아동의 발달 단계 중 영유아기는 매우 중요한 시기로 이 시기의 부모의 양육행동은 아동의 인지, 언어, 정서, 사회성 발달 등에 영향을 미치는 요인으로 강조되어 왔다. 1980년대

Corresponding Author: Hyun-Sim Doh, Department of Child Development \& Intervention, Ewha Womans University, 52, Ewhayeodae-gil, Seodaemun-gu, Seoul, 03760, Korea

E-mail: simdoh@ewha.ac.kr
중반 Belsky (1984)는 자녀양육과정 모델(a process model of the determinants of parenting)을 통해 부모의 양육행동은 부모, 자 녀 및 환경적 특성에 의하여 복합적으로 결정된다고 주장하였 다. 본 연구에서는 양육행동에 영향을 미치는 많은 요인들 중 양육행동에 직접적인 영향을 미치는 가정 내 부모의 영향을 살펴보기 위하여, 부부관계와 부모의 심리적 특성 중 행복감 및 우울감 및 양육행동 간의 관계를 강조한 Belsky (1984)의 자

(c)The Korean Association of Child Studies

This is an Open Access article distributed under the terms of the Creative Commons Attribution Non-Commercial License (http:// creativecommons.org/licenses/by-nc/4.0) which permits unrestricted noncommercial use, distribution, and reproduction in any medium, provided the original work is properly cited. 
녀양육과정 모델을 이론적 틀로 하였다.

부모의 결혼만족도, 행복감 및 우울감과 양육행동 간의 관 계와 관련하여, 어머니와 아버지 모두를 포함한 선행 연구들 은 대부분 각자의 독립적 영향력에 초점을 둠으로써 밀접한 부부간에 어떠한 방법으로 서로 영향을 미치는지에 탐색하 는 데 어려움이 있다. 이러한 문제를 해결하기 위한 대안으로 제안된 분석 모형이 자기-상대방 상호의존 모델(Actor-Partner Interdependence Model [APIM])이다(Cook \& Kenny, 2005). APIM모형을 활용하면 상호의존적 관계에 있는 부부의 양방 향 간 특성을 고려하여 파악할 수 있다(Ponnet et al., 2013). 특 히, 부부관계에서 자신의 영향(자기효과: actor effect)과 상대 방이 미치는 영향(상대방효과: partner effect)을 이해할 수 있 으며, 이를 통해 부부관계를 더 정확하게 이해할 수 있게 된다 (Cook \& Kenny, 2005).

그동안 많은 독립적 자료 형태의 연구결과들(Chae \& Kwak, 2017; Fishman \& Meyers, 2000; I. S. Han \& Yang, 2015; C. K. Kim \& Cho, 2015; H.-N. Kim \& Lee, 2013; Krishnakumar \& Buehler, 2000)에서 부모의 양육행동에 영향을 미치는 것으로 보고되는 부부관계가 부모 각각에 어떠한 인과적 과정을 거쳐 영향을 미치는지를 확인하기 위하여, 최근 들어 APIM을 통해 양자 간의 관계를 이해하고자 하는 연구가 점차 증가하고 있 다. 결혼불만족이 유아기 부모의 긍정적, 부정적 양육행동에 미치는 부부간의 자기효과와 상대방효과를 살펴본 연구(H.W. Kim \& You, 2017)에서 부모 모두에게 결혼불만족은 긍정 적 양육행동에 부적인 영향을 미치는 자기효과가 나타났으며, 상대방효과는 나타나지 않았다.

한편 Belsky (1984)는 양육행동에 영향을 미치는 주요한 요 인으로서의 부모의 심리적 특성을 긍정적 심리적 상태와 부 정적 심리적 상태로 나누어 설명하였다. 심리적 안녕감이라 고 일컬어지는 긍정적 심리적 특성을 지칭하는 용어는 주관 적 안녕감, 행복감, 긍정 정서, 삶의 만족도 등 다양한 용어가 혼재되어 사용되고 있으며, 다양한 방법으로 측정되고 있다 (Kwon, 2008; Yoo, 2016). 본 연구에서는 부모의 심리적 안녕 감을 종합적이고 포괄적으로 포함할 수 있는 행복감(subjective happiness)에 초점을 두었다(Lyubomirsky \& Lepper, 1999). 반 면 부정적 심리적 특성으로는 슬픔이나 불안감, 분노감 등이 있으나 아동에게 매우 부정적 양육행동을 할 가능성이 높다 고 밝혀진(Belsky, 1984), 전반적인 부정적 심리적 특징을 포괄 할 수 있는 우울감(depression)에 초점을 두었다(Kessler et al., 2002).

긍정적 심리적 특성인 행복감과 부정적 심리적 특성인 우
울감과 같은 긍정적, 부정적 심리적 특성 사이의 독립성은 오 랜 시간 동안 논란이 되어왔다(Argyle, 2001; Kwon, 2008). 이러 한 논란은 두 가지의 심리적 특성이 연속선상의 양 극단에 위 치하는지의 여부에 대한 것이다. 즉, 긍정적 심리적 특성과 부 정적 심리적 특성이 서로 반대에 있는 것이라면 행복감을 느 끼는 상태는 우울감을 느낄 수 없고, 우울감을 느끼는 상태라 면 행복감은 느낄 수 없는 것을 의미한다. 그러나 만약 두 정서 가 독립적이라면 사람들은 두 정서를 동시에 느낄 수 있다는 것이다. 선행 연구들(Argyle, 2001; Baumgardener \& Crothers, 2009; Compton, 2005; Diener, Emmons, Larsen, \& Griffin, 1985) 에서는 두 특성이 단일차원이라고 보기도 하고 독립적이라고 보기도 하였다. 최근에는 두 정서가 독립적이라고 보는 견해 가 우세하다(Compton, 2005). 선행 연구에서 행복감과 우울감 이 마치 거울에 비친 형상과 같이 정반대되는 개념인지를 확 인한 결과(Cheng \& Furnham, 2003) 행복감과 관련이 있었지 만 우울감의 예측요인이 아닌 것도 있었고 우울감과 관련이 있었지만 행복감의 예측 예측요인이 아닌 것도 있었다. 즉, 행 복감과 우울감에 영향을 미치는 요인들이 다를 수 있기 때문 에 행복감의 증진과 우울감의 감소는 다른 독립적 과정일 수 있다. 따라서 부정적 심리적 특성으로 대표되는 우울감과 긍 정적 심리적 특성으로 대표되는 행복감의 문제를 다룸에 있어 서 우울감을 감소시키는 방법과 중립 정서를 행복감으로 변화 시키는 방법이 다를 수 있다(Peterson, 2006; Peterson \& Steen, 2002). 그러나 같은 변인들 간의 관계 내에서 행복감과 우울감 의 독립성 또는 차이를 살펴본 연구는 매우 드물었다. 따라서 본 연구에서는 결혼만족도가 양육행동에 미치는 영향에서 행 복감과 우울감의 영향이 독립적인가를 검증하고자 하였다.

한편 부모의 행복감 및 우울감은 양육행동의 선행 변인으 로 보고되고 있다. 부모의 우울감과 비교할 때, 부모의 행복 감이 양육행동에 미치는 영향에 대한 연구들은 부모의 우울 감이 양육행동에 미치는 영향에 대한 연구들에 비해 매우 부 족한 편이다. Seligman과 Csikszentmihalyi (2000)는 긍정심리 학(positive psychology)의 필요성을 주장하며 현재까지의 연구 들은 부정적 심리적 특성이 개인에게 미치는 부정적 영향에 대한 연구들에 집중되어 왔던 것을 비판하였다. 이제는 긍정 적이고 행복한 심리적 특성이 인간에게 미치는 긍정적 영향 에 대한 연구들이 필요한 시점이라고 주장하였다(Seligman \& Csikszentmihalyi, 2000). 이와 관련하여 유아기 자녀를 둔 부모 의 심리적 특성과 긍정적 양육태도 간의 관계를 APIM을 통해 살펴본 연구에서(Yeon \& Choi, 2014) 부모 자신의 심리적 특 성이 건강할수록 긍정적 양육태도를 보이는 자기효과가 나타 
났지만 상대방효과는 나타나지 않았다. 즉, 어머니와 아버지 모두에게 배우자의 심리적 상태보다는 자신의 심리적 건강상 태가 부모의 긍정적 양육행동에 더 큰 영향을 미쳤다.

앞서 언급하였듯이, 부모의 우울감이 부모의 양육행동에 부정적 영향을 미친다는 점은 행복감이 양육행동에 미치는 영 향에 대한 연구들에 비해 오래전부터 지속적으로 연구되어 왔다(Gelfand \& Teti, 1990). 우울감은 어린 자녀를 둔 부모들 에서 유병률이 매우 높은 것으로 보고되고 있으며(J. Y. Lee \& Jang, 2009) 어머니와 아버지 모두에게 우울감은 양육행동에 부정적인 영향을 미치는 것으로 잘 알려져 있다(Davis, Davis, Freed, \& Clark, 2011; White \& Barrowclough, 1998; Wilson \& Durbin, 2010). 그러나 행복감의 경우와 마찬가지로 부모의 우 울감과 양육행동 간의 관계를 APIM을 이용해서 살펴본 연구 는 소수에 불과하다. 이와 관련하여 영아기 어머니가 산후 우 울을 겪고 있는 경우 아버지의 양육 스트레스가 증가한 반면 (Goodman, 2008) 어머니가 우울할 경우 아버지는 아동에게 더 나은 상호작용을 제공하기 위해 노력하고, 아동에게 보상 을 제공하고자 하였다(Edhborg, Lundh, Semiyr, \& Widstrom, 2003; Hossian et al., 1994).

위와 같이 부모의 결혼만족도는 양육행동에 영향을 미치며 심리적 특성인 행복감 및 우울감도 양육행동에 각각 긍정적, 부정적 영향을 미칠 수 있다. 또한 양육행동에 영향을 미치는 선행 요인들로 제시한 부모의 결혼만족도와 행복감 및 우울 감 또한 관련이 있는 것으로 보고되고 있다. 부모의 결혼만족 도와 행복감 간의 관계와 관련하여 부모가 결혼만족도를 높게 지각할수록 어머니의 심리적 안녕감 또는 삶의 만족도가 높았 다(H. O. Lee \& Kim, 2016; H. K. Park \& Youn, 2012). 청소년기 부모들을 대상으로 부부적응이 어머니와 아버지의 우울감에 미치는 영향을 APIM을 이용해 살펴본 연구(Beach, Katz, Kim, $\&$ Brody, 2003)에서 어머니와 아버지 모두에게서 자기효과와 상대방효과가 발견되었다. 즉, 어머니와 아버지 모두 각자 지 각하는 결혼적응에 대한 인식이 자신의 우울감뿐만 아니라 배 우자의 우울감에도 영향을 미쳤다. 다음으로 부모의 결혼만 족도가 높을수록 자신의 행복감은 높아지고, 우울감은 낮아 질 가능성이 높으며(H. O. Lee \& Kim, 2016; Markman, Stanley, \& Bluranberg, 2001; H. K. Park \& Youn, 2012) 상대방 효과는 부모 간 다른 양상으로 나타날 수 있다(Beach et al., 2003; Joo, Jeon, \& Wang, 2015).

마지막으로 앞서 살펴본 부모의 결혼만족도, 행복감 및 우 울감, 그리고 양육행동 간의 밀접한 관련성은 부모의 결혼만 족도가 양육행동에 영향을 미치는 관계에서 행복감 및 우울
감의 매개적 역할을 가정하게 한다. 먼저 행복감의 매개적 역 할과 관련하여 아버지가 지각하는 부부생활의 질과 부모-자 녀관계 간의 관계에서 안녕감의 매개적 역할을 보고하였다 (Y.-R. Lee \& Park, 2009). 다음으로 우울감의 매개적 역할과 관 련하여 유아기 자녀를 둔 아버지의 우울감은 부부갈등과 양 육태도 간의 관계를 매개하였으며(Y.-S. Lee, 2017) 청소년기 자녀를 둔 부모의 우울감은 부부관계의 질과 부모-자녀 관계 의 질 간의 관계를 매개하였다(Kouros, Papp, Goeke-Morey, \& Cummings, 2014).

종합해 보면 본 연구는 이론적인 틀로서 Belsky (1984)의 자 녀양육과정 모델과 방법론적 틀로서 Cook과 Kenny (2005)의 $\mathrm{APIM}$ 을 활용하여 부모의 결혼만족도, 행복감 및 우울감, 양 육행동 간의 상호의존적, 역동적인 관계를 탐색함으로써 부모 의 결혼만족도와 양육행동 간의 관계에서 행복감 및 우울감의 매개효과에서의 자기-상대방효과를 살펴보았다. 본 연구에서 선정한 연구문제 및 연구모형은 다음과 같다(Figure 1,2).

\section{연구문제 1}

부모의 결혼만족도와 양육행동 간의 관계에서 행복감의 매개 효과에서의 자기-상대방효과는 어떠한가?

\section{연구문제2}

부모의 결혼만족도와 양육행동 간의 관계에서 우울감의 매개 효과에서의 자기-상대방효과는 어떠한가?

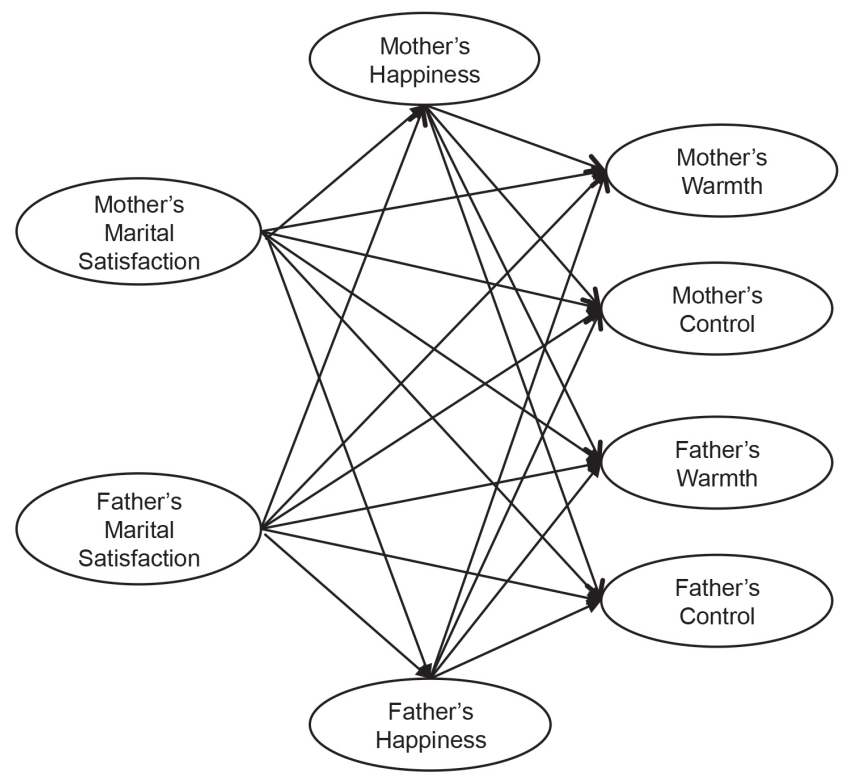

Figure 1. Indirect actor-partner effects of parents' marital satisfaction on parenting behaviors with happiness as mediator. 


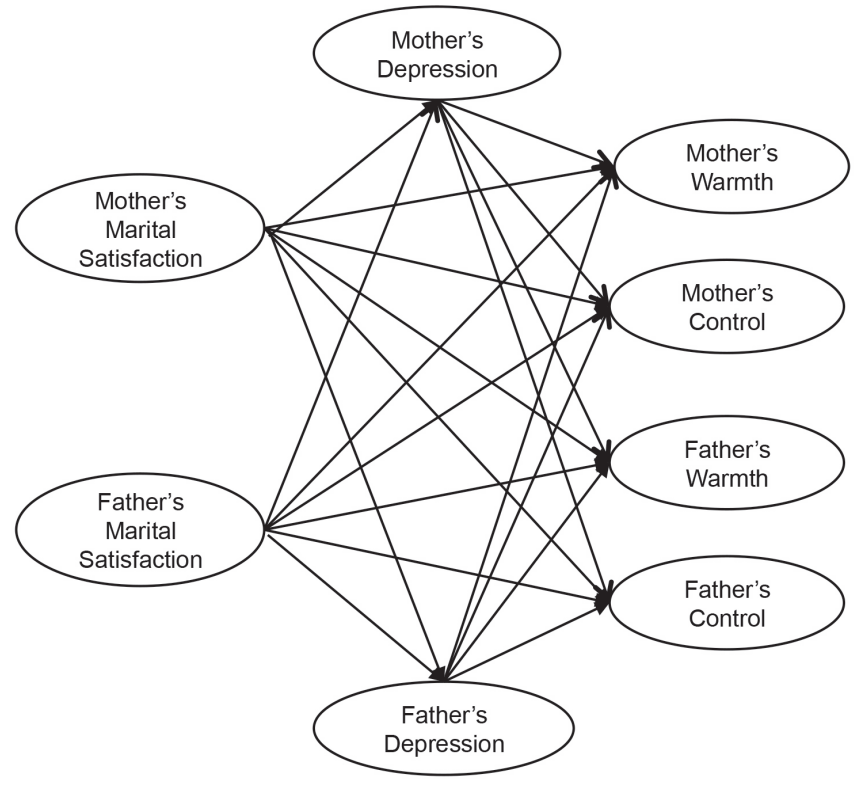

Figure 2. Indirect actor-partner effects of parents' marital satisfaction on parenting behaviors with depression as mediator.

\section{Methods}

\section{연구대상}

본 연구는 육아정책연구소의 한국아동패널조사(Panel Study on Korean Children [PSKC]) 자료 중 7차년도 자료(2014년, 만 4세)를 사용하였다. PSKC는 우리나라 아동의 출생 후 삶의 궤 적을 추적하고, 아동이 어떠한 환경에서 성장하고 있는가를 파악하기 위한 과학적 자료를 구축하고자 진행하고 있는 연구 이다(Korea Institute of Child Care and Education, 2014). 본 연구 의 참가자는 조사에 참여한 총 1,620 쌍의 자료 중 부모와 아이 가 함께 살고 있지 않은 경우(12가구)와 대부분의 문항에 불성 실한 응답을 한 경우(95가구)를 제외한 1,513 가구의 어머니와 아버지들이다. 유아기 자녀 부모들을 연구 참가자로 선정한 이유는 이 시기 자녀를 둔 부모의 양육행동은 영아기에 이어 아동의 성장과 발달에 많은 영향을 미치며, 여전히 양육행동 의 중요성이 강조되는 시기이기 때문이다(C.-K. Kim \& Cho, 2015). 특히 본 연구는 어머니뿐만 아니라 아버지도 연구 참가 자로 선정하였는데 이는 한국아동패널 연구 뿐 아니라 영국 의 1999-2000년 출생아 대상 밀레니엄 코호트 연구(Millenium Cohort Study [MCS])에서도 강조하고 있는 아버지의 중요성 과 더불어(Y. K. Choi et al., 2014) 부부와 같이 쌍을 이루는 대
상들은 커플 단위로 분석이 이루어져야 하며(Cook \& Kenny, 2005; Kenny, 1996) 양육행동에 대한 명확한 이해를 위해서는 어머니와 아버지를 동시에 고려하는 것이 매우 중요하다는 근 거에 따라(H.-S. Choi \& Yeon, 2014) 본 연구에서는 연구참가 자를 만 4세 유아기 자녀를 둔 어머니와 아버지로 선정하였다.

7 차년도 한국아동패널에 조사에 참여한 총 1,620 쌍의 자료 중 부모와 아이가 함께 살고 있지 않은 경우(12가구)와 대부분 의 문항에 불성실한 응답을 한 경우(95가구)을 제외한 1,513 쌍의 자료를 분석하였다. 아동의 성별은 남아 774 명 $(51.2 \%)$, 여아 739 명 $(48.8 \%)$ 이었다. 부모의 학력과 관련하여 4 년제 졸 업이 어머니와 아버지 각각 572명(37.8\%)과 634명(41.9\%)으 로 가장 많았으며, 어머니 직업은 전문가 및 관련 종사자가 288 명(19.0\%)으로 가장 많았고, 아버지 직업은 사무 종사자가 327 명 $(21.6 \%)$ 으로 가장 많았다. 어머니의 취업여부는 취업모 와 비취업모가 각각 676명(44.7\%)과 829명(54.8\%)이었다. 거 주지역은 경인권이 475 가구로 가장 많았고(31.4\%) 부산, 울 산, 경남권이 262 가구(17.3\%)로 그 다음 순이었다. 가구의 구 성형태는 부모, 자녀 가구가 1368 가구(90.4\%)로 가장 많았고, 부모의 연령은 어머니는 35-39세가 770명(50.9\%)으로 가장 많았고, 아버지는 35-39세가 637명(42.1\%)으로 가장 많았다. 월 평균 가구소득은 300-600만원 미만이 1053가구(69.6\%)로 가장 많았고, 0-300만원 미만이 310가구(20.5\%), 600-900만 원 미만이 115 가구(7.6\%), 900-1200미만이 33가구(2.2\%)가구, 1200 만원 이상이 2 가구( $0.1 \%)$ 순이었다.

\section{연구도구}

\section{결혼만족도}

부모의 결혼만족도 척도는 수정된 캔자스 결혼만족도 척도 (Revision of the Kansas Marital Satisfaction Scale [RKMSS])로 서 이 척도는 Chung (2004)의 캔자스 결혼만족도 척도(Kansas Marital Satisfaction Scale [KMSS])를 육아정책연구소에서 우리나 라 문화에 맞게 수정한 것이다(Schumm, Nicohols, Schectman, \& Grigsby, 1983). 이 척도는 "귀하는 배우자로서의 남편(아내)에 대하여 얼마나 만족하십니까?”, “귀하는 결혼생활에 얼마나 만 족하십니까?” 등 4개 문항으로 구성된 4점 리커트 척도이다. 문 항 간 내적 합치도는(Cronbach' $\alpha$ ), 어머니의 결혼만족도는 .93, 아버지의 결혼만족도는 .93 이었다. 
행복감

부모의 행복감 척도는 Lyubomirsky와 Lepper (1999)의 주관적 행복감(subjective happiness) 척도를 한국아동패널 연구진들이 번안하여 예비조사 실시 후에 문항을 확정한 것이다. 총 4문항, 7점 리커트 척도로 구성되어 있으며, "어떤 사람들은 전반적으 로 아주 행복하다.", "무슨 일이 있어도 개의치 않고 즐겁게 지 내는 편이다.", "나는 매우 그렇다.", "어떤 사람들은 전반적으 로 아주 불행하다.", "특별히 우울한 일이 없음에도 불구하고 행복하지 않게 보인다.", "나는 전혀 그렇지 않다." 등과 같은 문항들로 구성되어 있다. 문항 간 내적 합치도는(Cronbach' $\alpha$ ), 어머니의 행복감은 .88 , 아버지의 행복감은 .87 이었다.

\section{우울감}

부모의 우울감 척도는 Kessler 등(2002)의 우울 척도를 한국아 동패널 연구진이 번안한 것이다. 이 척도는 총 6 개 문항의 5 점 리커트 척도로 구성되어 있으며 문항의 예를 들면, "지난 30 일 동안 불안감을 느끼셨습니까?”, “지난 30일 동안 무기력하셨 습니까?”, “지난 30 일 동안 안절부절 못하셨습니까?” 등이 포 함된다. 문항 간 내적 합치도는(Cronbach' $\alpha$ ), 어머니의 우울감 .92 , 아버지의 우울감 .93 이었다.

\section{양육행동}

부모의 양육행동 척도는 Cho, Lee, Lee와 Kwon (1999)의 문항 을 참고하여 한국아동패널 연구진이 자체 제작한 것이다. 부 모의 양육행동은 두 가지 하위요인으로 구성되어 있으며(총 12 문항), 온정성(6문항)과 통제성(6문항)으로 구성되어 있다. 이 척도는 5점 리커트 척도로 구성되어 있으며 점수가 높을 수록 온정성, 통제성이 높은 양육행동을 의미한다. 온정성 문 항의 예로서, "아이와 친밀한 시간을 갖는다.", "아이와 이야 기해주고 놀아준다." 등을 통제성의 경우 "아이가 어려도 엄 격하게 예절을 가르친다.", "아이가 잘못 했을 때는 반드시 벌 을 주고 반성하게 한다." 등을 들 수 있다. 문항 간 내적 합치도 (Cronbach' $\alpha$ )는, 어머니의 온정성은 .86 , 어머니의 통제성은 .73 , 아버지의 온정성은 .73 , 아버지의 통제성은 .79 이었다.

\section{통제변인}

본 연구에서는 연구변인들 간의 관계에서 영향을 미칠 수
있는 아동의 성별, 가구 소득과 어머니의 취업여부를 통제 하였다. 선행 연구들에 따르면 가구소득(Duncan, BooksGunn, \& Klebanov, 1994; K.-Y. Lee, 2002), 어머니의 취업여 부(Greenberger, Goldberg, Hamill, O'neil, \& Payne, 1989; J. H. Han \& Hong, 2000)는 부모의 양육행동에 영향을 미치는 주 요 요인이었다. 가구소득은 지난 1년 동안의 월 평균 가구소득 (실 수령액 기준)에 의해 측정하였다. 한국아동패널 조사를 활 용한 선행 연구(Kang \& Park, 2013; Yeon, Yoon, \& Choi, 2016) 들에 기초하여 월평균 가구소득 사분위수의 하위 $25 \%$ 미만은 가구소득이 낮은 집단, $25 \%$ 이상 $75 \%$ 미만은 가구소득이 중간인 집단, $75 \%$ 이상은 가구소득이 높은 집단으로 분류하 여 살펴보았다. 또한 어머니의 취업여부는 취업 중인 경우와 취업과 학업을 병행 중인 어머니는 취업모로, 학업 중인 어머 니를 포함하여 미취업한 어머니는 비취업모로 구분하였다.

\section{연구절차}

한국아동패널은 한 아동이 출생하여 성인 초기인 20세가 될 때까지 장기간 동안의 발달과 양육의 변화를 계속적으로 추적 하고, 조사하기 위한 목적으로 육아정책연구소 주관으로 매년 실시되고 있으며 2016년 기준으로 연간 분간건수가 500건 이 상인 표본 의료기관에서 2008년 4월부터 7월 사이에 출생한 신생아 가구 중 패널 참여의사가 있는 2,150 명의 신생아 가구 를 표본으로 추출하였다(J. R. Lee et al., 2015). 표본 추출은 층 화 다단계 표본 추출법(multiple stage stratified sampling)을 적용 하였는데 1 단계에서는 신생아 분만이 이루어지는 의료기관을 선정하고, 2 단계에서는 선정된 의료기관에서 출생한 신생아 가구를 예비표본으로 추출하였으며, 3 단계에서는 예비표본 가구 중 패널 참여의사가 있는 가구를 표본으로 구축하였다(J. R. Lee et al., 2015).

\section{자료분석}

본 연구는 SPSS 23.0 (IBM Co., Armonk, NY)과 AMOS 23.0 (IBM Co., Armonk, NY) 프로그램을 이용하여 자료를 분석하 였다. 첫째, 연구대상의 사회인구학적 특성을 확인하기 위하 여 빈도분석을 실시하였다. 둘째, 각 척도의 신뢰도를 확인하 기 위하여 문항내적합치도(Cronbach' $\alpha$ ) 계수를 산출하였다. 셋째, 주요 변인들의 평균과 표준편차를 산출하고 자료의 정 규 분포 가정 충족 여부를 확인하기 위하여 왜도와 첨도 값을 확인하였다. 넷째, 주요 변인 간의 연관성을 확인하기 위하여 
상관계수를 산출하였다. 다섯째, 부모의 결혼만족도가 양육행 동에 미치는 영향에서 행복감과 우울감의 매개모형을 각각 설 정한 후, 구조모형 검증을 실시하여 각 모형의 적합도와 직간 접 경로들의 자기-상대방효과를 분석하고, 이 때 매개효과를 검증하기 위하여 부트스트래핑(bootstrapping) 방법을 적용하 였다. 마지막으로, 구조모형에서 개별 간접 효과를 확인하기 위하여 소벨 테스트(sobel test)를 실시하였다.

구조모형을 검증하기에 앞서 Russell, Kahn, Spoth와 Altmaier (1998)가 제시한 문항 꾸러미(item parcels)를 제작하였다. 문항 꾸러미는 여러 문항을 몇 개씩 결합하여 측정변인을 제작한 후 분석에 이용하는 것으로 다음과 같은 이점이 있다(Y. S. Seo, 2010). 개별문항을 그대로 사용했을 때 생길 수 있는 비정규성 문제를 줄이고, 측정변인이 몇 문항의 합이나 평균으로 이루어 지므로 신뢰도가 높아진다. 또한 추정해야 하는 모수들의 숫자 가 감소하여 측정오차가 줄어들고 모형의 적합도가 좋아진다 (Bandalos, 2002). 본 연구에서는 측정모형에 사용되는 8 개의 측 정변인 모두 단일요인이며 문항의 수는 4-6개로 많지 않은 것 을 감안하여 결혼만족도, 행복감과 우울감, 양육행동 각 변인 당 2 개의 문항 꾸러미를 산출하였다. 문항 꾸러미는 개념으로 묶는 방법과 요인부하량을 기준으로 묶는 방법이 있는데 본 연 구에서는 자료의 정규성 문제를 줄이는 데 더 유리하다는 점에 서(Little, Rhemtulla, Gibson, \& Schoemann, 2013) 후자를 이용 하였다. 문항 꾸러미는 각 변인에서 1 개 요인으로 고정된 탐색 적 요인분석을 실시한 후 요인부하량을 기준으로 요인부하량 이 높은 순서대로 문항들을 배열한 다음 두 개의 꾸러미가 비 슷한 요인부하량이 갖도록 할당하였다. 즉, 각 변인들에서 문 항의 순위를 매겨 요인부하량이 가장 높은 문항부터 순차적으 로 두 개 꾸러미에 할당하여 각 꾸러미가 잠재변인에 대해 유 사한 요인을 갖도록 생성하였다(Y. S. Seo, 2010).

구조모형 검증은 2단계 접근법(Anderson \& Gerbing, 1988) 을 활용하였다. 먼저 측정변인들이 잠재변인들을 적절하게 구 인하고 있는지를 확인하기 위하여 확인적 요인분석을 통해 측 정모형 검증을 실시하였다. 다음으로는 구조모형의 적합도를 확인하고 각 경로의 유의도를 확인하였다. 모형의 적합도는 Normed Fit Index (NFI), Tucker-Lewis Index (TLI), Comparative Fit Index (CFI), Root Mean Square Error of Approximation (RMSEA)등을 중심으로 판단하였다. NFI, TLI, CFI는 .90이 상이면 좋은 적합도(Bentler, 1990; Bentler \& Bonett, 1980), RMSEA는 .05미만이면 좋은 적합도, .08미만이면 괜찮은 적 합도, .10미만이면 보통 적합도, .10이상이면 나쁜 적합도 (Browne \& Cudeck, 1993)로 판단한다. 한편 구조모형 검증 시
에 가구의 가구소득과 어머니의 취업여부를 통제하였다.

\section{Results}

\section{주요 변인의 기술 통계 및 상관분석}

본 분석에 앞서 본 연구의 주요 변인인 부모의 결혼만족도, 행 복감 및 우울감, 양육행동과 통제변인 중 연속 변수인 가구소 득의 일반적 경향성과 정규분포 가정 충족 여부를 확인하기 위하여 평균, 표준편차, 왜도 및 첨도를 산출하였으며 그 결 과를 Table 1 에 제시하였다. 변인의 왜도의 절대값은 3 보다 작 고 첨도는 8보다 작아야 정규성을 이루는 것으로 판단할 수 있 는데(Kline, 2015), 제곱근 변환을 한 가구소득은 평균 20.87, 표준편차는 3.91로 나타났으며, 가구소득 변인을 포함한 모 든 측정 변인의 왜도 범위는 -2.38 1.18, 첨도 범위는 -1.96 6.53으로 나타나 자료의 정규성 문제가 없음을 확인하였다. 다음으로 연구변인들 간의 관계를 살펴보기 위해 Pearson의 상 관계수를 산출한 결과는 Table 1과 같다.

\section{결혼만족도와 양육행동 간 관계에서 행복감과 우울감의 매개효과에서의 자기-상대방효과}

결혼만족도와 양육행동 간 관계에서 행복감과 우울감의 매개 효과에서의 자기-상대방효과를 분석하기 전에 앞서, 기본모 형에서 추정된 효과의 비교를 위해서 어머니와 아버지의 결혼 만족도와 행복감 및 우울감, 양육행동의 각 변인 간 관계에서 의 자기-상대방효과의 기본 모델과 비교하였다. 모든 모형에 서 모형의 적합도는 $\chi^{2}=34.66 \sim 155.51, p<.001, \mathrm{TLI}=.956$ $\sim .968, \mathrm{CFI}=.998 \sim .984, \mathrm{RMSEA}=.026 \sim .069$ 로 양호한 수준 에 속하였다. 연구변인들 간의 자기-상대방효과와 관련하여 어머니와 아버지의 결혼만족도가 행복감 및 우울감, 온정성 및 통제성에 미치는 영향에서 자기효과와 상대방효과가 나타 났다. 어머니와 아버지의 행복감 및 우울감이 온정성과 통제 성에 미치는 영향의 경우 어머니와 아버지의 행복감이 온정성 과 통제성에 미치는 자기효과와 어머니의 행복감이 아버지의 온정성에 미치는 상대방효과가 나타났으며, 어머니와 아버지 의 우울감이 온정성에 미치는 자기효과와 아버지의 우울감이 통제성에 미치는 자기효과, 그리고 아버지의 우울감이 어머니 의 온정성에 미치는 상대방효과가 나타났다. 
Table 1

Descriptive Statistics and Correlation Coefficients among Variables

\begin{tabular}{|c|c|c|c|c|c|c|c|c|c|c|}
\hline & 1 & 2 & 3 & 4 & 5 & 6 & 7 & 8 & 9 & 10 \\
\hline 1 & - & & & & & & & & & \\
\hline 2 & $.54^{* * *}$ & - & & & & & & & & \\
\hline 3 & $-.43^{* * *}$ & $-.63^{* * *}$ & - & & & & & & & \\
\hline 4 & $.27^{* * *}$ & $.38^{* * *}$ & $-.33^{* * *}$ & - & & & & & & \\
\hline 7 & $.34^{* * *}$ & $.41^{* * *}$ & $-.30^{* * *}$ & $.18^{* * *}$ & .04 & $.52^{* * *}$ & - & & & \\
\hline 8 & $-.29^{* * *}$ & $-.26^{* * *}$ & $.36^{* * *}$ & $-.13^{* * *}$ & -.00 & $-.35^{* * *}$ & $-.53^{* * *}$ & - & & \\
\hline 9 & $.33^{* * *}$ & $.24^{* * *}$ & $-.21^{* * *}$ & $.31^{* * *}$ & $.06^{* *}$ & $.32^{* * *}$ & $.37^{* * *}$ & $-.30^{* * *}$ & - & \\
\hline 10 & $.06^{*}$ & .02 & -.01 & .01 & $.27^{* * *}$ & $.06^{* *}$ & .03 & -.02 & $.14^{* * *}$ & - \\
\hline Skewness & -.96 & -.65 & .88 & -.31 & -.33 & -1.05 & -.28 & 1.18 & -.28 & -.09 \\
\hline Kurtosis & 2.35 & 1.66 & 1.85 & 2.30 & 2.50 & 2.53 & .86 & 3.49 & 2.14 & 1.67 \\
\hline
\end{tabular}

Note. $N=1,513$ couples. 1 = mother's marital satisfaction; 2 = mother's happiness; 3 = mother's depression; $4=$ mother's warmth; $5=$ mother's control 6 = father's marital satisfaction; 7 = father's happiness; 8 = father's depression; 9 = father's warmth; $10=$ father's control.

${ }^{*} p<.05 .{ }^{* *} p<.01 .{ }^{* * *} p<.001$.

결혼만족도와 양육행동 간 관계에서 행복감의 매개효과에서의 자기-상대방효과

구조모형을 검증하기에 앞서 측정변수들이 부모의 결혼만족 도, 행복감, 온정성 및 통제성의 잠재변수를 적절하게 구인하 고 있는지를 확인하기 위하여 확인적 요인분석을 실시하였다. 어머니의 통제성 1 번 문항 꾸러미와 아버지의 통제성 1 번 문항 꾸러미의 오차 분산이 음수(헤이우드 케이스)로 나타나 이를 0.0005 로 고정한 후 분석을 실시하였다. 그 결과 측정모형의 적 합도는 NFI $=.963, \mathrm{TLI}=.949, \mathrm{CFI}=.967, \mathrm{RMSEA}=.064$ 로 양 호하게 나타나 적합한 모형임을 확인하였다. 가구소득은 아버 지의 온정성 $(\beta=.06, p<.01)$ 에 유의한 영향을 미쳤고, 어머니의 취업여부 및 아동의 성별의 영향력은 유의하지 않았다.

결혼만족도와 양육행동 간의 관계에서 행복감의 매개효과 검증을 실시하였다. 모형의 적합도는 $\chi^{2}=1418.92, d f=78, p<$ $.001, \mathrm{NFI}=.911, \mathrm{TLI}=.886, \mathrm{CFI}=.918, \mathrm{RMSEA}=.082$ 로 나타 났으며 경로계수를 Figure 3과 Table 2에 제시하였다. 먼저 직 접효과와 관련하여 자기효과의 경우 어머니의 결혼만족도는 어머니의 행복감에, 아버지의 결혼만족도는 아버지의 행복감 과 온정성에, 어머니의 행복감은 어머니의 온정성과 통제성 에, 아버지의 행복감은 아버지의 온정성과 통제성에 정적효과
가 나타났고( $\beta=.01 \sim .52, p<.01$ 또는 $p<.001)$, 상대방효과 의 직접효과를 살펴보면 어머니의 결혼만족도는 아버지의 행 복감, 온정성, 통제성에, 아버지의 결혼만족도는 어머니의 행 복감, 온정성, 통제성에 정적효과가 나타났다 $(\beta=.08 \sim .15, p$ $<.01$ 또는 $p<.001)$.

다음으로 부모의 결혼만족도가 양육행동에 미치는 매개 효과는 간접적 자기효과와 간접적 상대방효과로 구분된다 (Muraru \& Turlluc, 2015). 간접적 자기효과는 독립변수와 매개 변수 사이와 매개변수와 종수변수 사이에 모두 자기효과가 나 타나는 자기효과/자기효과와 독립변수와 매개변수 사이와 매 개변수와 종속변수 사이에 모두 상대방효과가 나타나는 상대 방효과/상대방효과가 있다. 간접적 상대방효과는 독립변수와 매개변수 사이에는 자기효과가 매개변수와 종속변수 사이에 는 상대방효과가 나타나는 자기효과/상대방효과와 독립변수 와 매개변수 사이에는 상대방효과가 매개변수와 종속변수 사 이에는 자기효과가 나타나는 상대방효과/자기효과가 있다.

Sobel Test를 활용한 매개효과는 Table 3과 같다. 먼저 부모 의 결혼만족도가 양육행동에 미치는 영향에서 행복감의 매개 효과에 대한 간접적 자기효과는 부모 모두에게 자기효과/자 기효과가 나타났다. 구체적으로 살펴보면 어머니의 결혼만족 도가 어머니의 행복감을 거쳐 어머니의 온정성에 영향을 미 


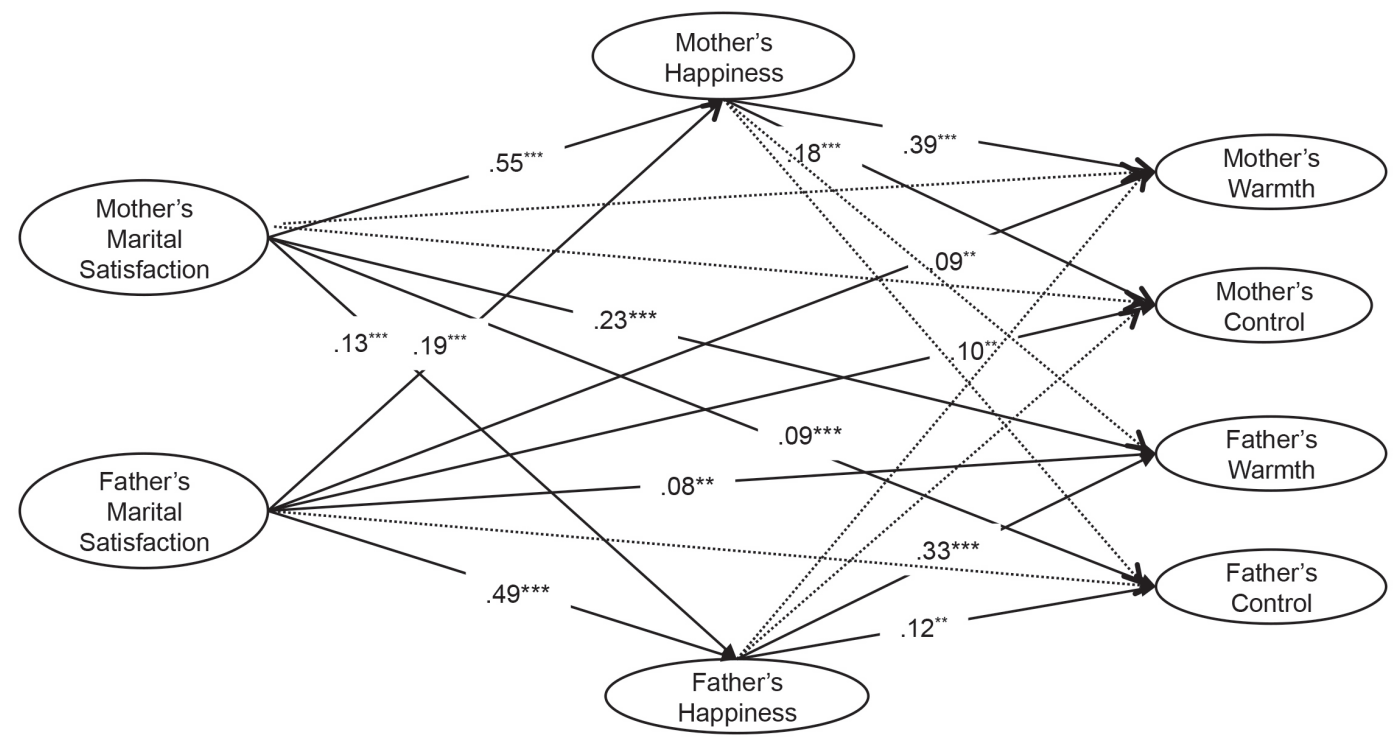

Figure 3. Indirect actor-partner effects of parents' marital satisfaction on parenting behaviors with happiness as mediator. Dotted lines indicate insignificant paths.

Table 2

Direct, Indirect Effects Among Marital Satisfaction, Happiness and Parenting Behaviors

\begin{tabular}{|c|c|c|c|c|}
\hline Path & $B$ & $S E$ & $\beta$ & $t$ \\
\hline \multicolumn{5}{|l|}{ Actor effect } \\
\hline Mother's marital satisfaction $\rightarrow$ Mother's happiness & .55 & .02 & .50 & $19.40^{* * *}$ \\
\hline Mother's marital satisfaction $\rightarrow$ Mother's warmth & .04 & .03 & .04 & 1.35 \\
\hline Mother's marital satisfaction $\rightarrow$ Mother's control & .01 & .03 & .01 & .21 \\
\hline Father's marital satisfaction $\rightarrow$ Father's happiness & .49 & .03 & .52 & $19.57^{* * *}$ \\
\hline Father's marital satisfaction $\rightarrow$ Father's warmth & .08 & .03 & .08 & $2.68^{* *}$ \\
\hline Father's marital satisfaction $\rightarrow$ Father's control & .07 & .04 & .06 & 1.77 \\
\hline Mother's happiness $\rightarrow$ Mother's warmth & .39 & .04 & .39 & $10.93^{* * *}$ \\
\hline Mother's happiness $\rightarrow$ Mother's control & .18 & .04 & .17 & $4.67^{* * *}$ \\
\hline Father's happiness $\rightarrow$ Father's warmth & .33 & .04 & .31 & $8.81^{* * *}$ \\
\hline Father's happiness $\rightarrow$ Father's control & .12 & .04 & .10 & $2.74^{* *}$ \\
\hline \multicolumn{5}{|l|}{ Partner effect } \\
\hline Mother's marital satisfaction $\rightarrow$ Father's happiness & .13 & .02 & .15 & $6.53^{* *}$ \\
\hline Mother's marital satisfaction $\rightarrow$ Father's warmth & .23 & .03 & .27 & $8.64^{* * *}$ \\
\hline Mother's marital satisfaction $\rightarrow$ Father's control & .09 & .03 & .09 & $2.90^{* * *}$ \\
\hline Father's marital satisfaction $\rightarrow$ Mother's happiness & .19 & .02 & .20 & $8.43^{* * *}$ \\
\hline Father's marital satisfaction $\rightarrow$ Mother's warmth & .09 & .03 & .08 & $2.69^{* *}$ \\
\hline Father's marital satisfaction $\rightarrow$ Mother's control & .10 & .03 & .09 & $2.89^{* *}$ \\
\hline Mother's happiness $\rightarrow$ Father's warmth & -.06 & .04 & -.06 & -1.27 \\
\hline Mother's happiness $\rightarrow$ Father's control & -.06 & .04 & .05 & -1.37 \\
\hline Father's happiness $\rightarrow$ Mother's warmth & -.06 & .04 & -.05 & -1.47 \\
\hline Father's happiness $\rightarrow$ Mother's control & -.08 & .04 & -.07 & -2.01 \\
\hline
\end{tabular}

Note. $N=1,513$.

${ }^{*} p<.05 .{ }^{* *} p<.01 .{ }^{* * *} p<.001$. 
Table 3

Indirect Actor-Partner Effects of Parents' Marital Satisfaction on Parenting Behaviors with Happiness as Mediator

\begin{tabular}{lcccc}
\hline & \multicolumn{2}{c}{ Indirect actor effects } & \multicolumn{2}{c}{ Indirect partner effects } \\
\cline { 2 - 5 } \multicolumn{1}{c}{ Dimension } & Actor/Actor & Partner/Partner & Actor/Partner & Partner/Actor \\
\hline Mother's warmth & $.02^{* * *}$ & - & - & $.08^{* * *}$ \\
Father's warmth & $.18^{* * *}$ & - & - & $.05^{* * *}$ \\
Mother's control & $.09^{* * *}$ & - & - & $.08^{* * *}$ \\
Father's control & $.10^{* * *}$ & - & $.05^{* * *}$ \\
\hline
\end{tabular}

Note. $N=1,513$. '-' shows that analyses on mediation effects could not be conducted because correlations between variables were not significant.

${ }^{*} p<.05 .{ }^{* *} p<.01 .{ }^{* * *} p<.001$.

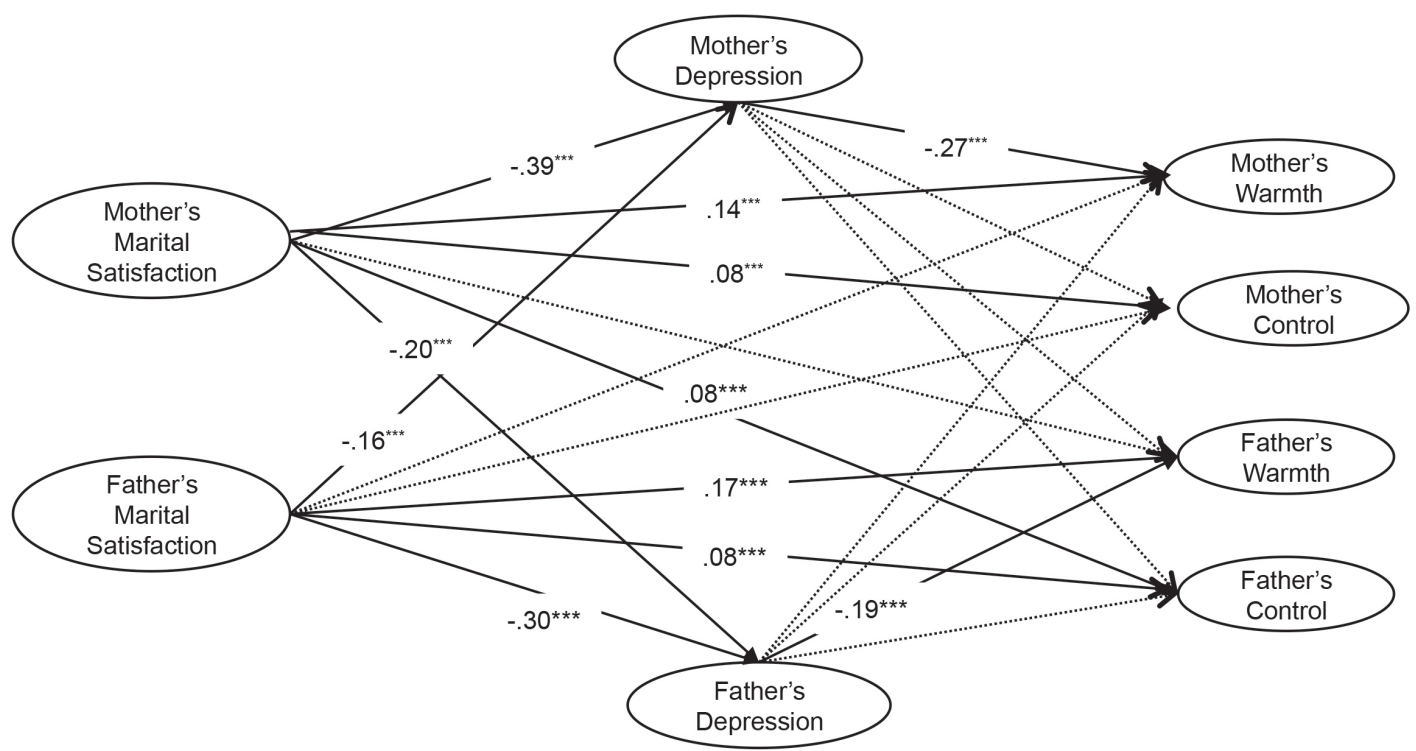

Figure 4. Indirect actor-partner effects of parents' marital satisfaction on parenting behaviors with depression as mediator. Dotted lines indicate insignificant paths.

치는 자기효과/자기효과(완전매개)가 나타났다 $(\beta=.02, p<$ .001). 또한 어머니의 결혼만족도가 어머니의 행복감을 거쳐 어 머니의 통제성에 영향을 미치는 자기효과/자기효과(완전매개) 가 나타났다 $(\beta=.09, p<.001)$. 또한 아버지의 결혼만족도가 아 버지의 행복감을 거쳐 아버지의 온정성에 영향을 미치는 자기 효과/자기효과(부분매개)가 나타났으며 $(\beta=.18, p<.001)$, 아 버지의 결혼만족도가 아버지의 행복감을 거쳐 아버지의 통제 성에 영향을 미치는 자기효과/자기효과(완전매개)가 나타났다 $(\beta=.10, p<.001)$. 다음으로 부모의 결혼만족도가 양육행동에 미치는 영향에서 행복감의 매개효과에 대한 간접적 상대방효 과는 부모 모두에게 상대방효과/자기효과가 나타났다. 어머니 의 결혼만족도가 아버지의 행복감을 거쳐 아버지의 온정성에 영향을 미치는 상대방효과/자기효과(부분매개)가 나타났으며 $(\beta=.05, p<.001)$, 어머니의 결혼만족도가 아버지의 행복감을
거쳐 아버지의 통제성에 영향을 미치는 상대방효과/자기효과 (부분매개)가 나타났다 $(\beta=.05, p<.001)$. 또한 아버지의 결혼 만족도가 어머니의 행복감을 거쳐 어머니의 온정성에 영향을 미치는 상대방효과/자기효과(부분매개)가 나타났으며( $\beta=.08$, $p<.001)$, 아버지의 결혼만족도가 어머니의 행복감을 거쳐 어 머니의 통제성에 영향을 미치는 상대방효과/자기효과(부분매 개)가 나타났다( $\beta=.08, p$ <Pasted Graphic 4.bmp .001).

\section{결혼만족도와 양육행동 간 관계에서 우울감의 매개효과에서의 자기-상대방효과}

구조모형을 검증하기에 앞서 측정변수들이 부모의 결혼만족 도, 우울감, 온정성, 통제성의 잠재변수를 적절하게 구인하고 있는지를 확인하기 위하여 확인적 요인분석을 실시하였다. 어 
Table 4

Direct, Indirect Effects Among Marital Satisfaction, Depression, and Parenting Behaviors

\begin{tabular}{|c|c|c|c|c|}
\hline Path & $B$ & $S E$ & $\beta$ & $t$ \\
\hline \multicolumn{5}{|l|}{ Actor effect } \\
\hline Mother's marital satisfaction $\rightarrow$ Depression & -.38 & .03 & -.39 & $-15.23^{* * *}$ \\
\hline Mother's marital satisfaction $\rightarrow$ Control & .78 & .03 & .08 & $2.85^{* *}$ \\
\hline Father's marital satisfaction $\rightarrow$ Depression & -.31 & .03 & -.30 & $-11.29^{* * *}$ \\
\hline Father's marital satisfaction $\rightarrow$ Control & .10 & .03 & .08 & $3.18^{* *}$ \\
\hline Mother's depression $\rightarrow$ Warmth & -.25 & .03 & -.27 & $-8.75^{* * *}$ \\
\hline Mother's depression $\rightarrow$ Control & -.02 & .03 & -.02 & -.69 \\
\hline Father's depression $\rightarrow$ Warmth & -.19 & .03 & -.19 & $-6.52^{* * *}$ \\
\hline Father's depression $\rightarrow$ Control & -.08 & .03 & -.05 & -1.72 \\
\hline Father's marital satisfaction $\rightarrow$ Fathers control & .09 & .03 & .08 & $2.82^{* *}$ \\
\hline Father's marital satisfaction $\rightarrow$ Mother's depression & -.17 & .03 & -.16 & $-6.26^{* * *}$ \\
\hline Father's marital satisfaction $\rightarrow$ Mother's warmth & .10 & .03 & .10 & 3.67 \\
\hline Father's marital satisfaction $\rightarrow$ Mother's control & .10 & .03 & .06 & 3.47 \\
\hline Mother's depression $\rightarrow$ Father's warmth & .01 & .03 & .01 & .21 \\
\hline Mother's depression $\rightarrow$ Father's control & .03 & .03 & .03 & .54 \\
\hline Father's depression $\rightarrow$ Mother's warmth & .05 & .03 & .06 & 1.89 \\
\hline Father's depression $\rightarrow$ Mother's control & .04 & .03 & .04 & 1.51 \\
\hline
\end{tabular}

Note. $N=1,513$.

${ }^{*} p<.05 .{ }^{* *} p<.01{ }^{* * *} p<.001$.

Table 5

Indirect Actor-Partner Effects of Parents' Marital Satisfaction on Parenting Behaviors with Depression as Mediator

\begin{tabular}{lccccc}
\hline & \multicolumn{2}{c}{ Indirect actor effects } & & \multicolumn{2}{c}{ Indirect partner effects } \\
\cline { 1 - 3 } \multicolumn{1}{c}{ Dimension } & Actor/Actor & Partner/Partner & & Actor/Partner & Partner/Actor \\
\hline Mother's warmth & $.11^{* * *}$ & - & - & - & $.04^{* * *}$ \\
Father's warmth & $.10^{* * *}$ & - &. & $.10^{* * *}$ \\
\hline
\end{tabular}

Note. $N=1,513$. '-' shows that analyses on mediation effects could not be conducted because correlations between variables were not significant. ${ }^{*} p<.05 .{ }^{* *} p<.01 .{ }^{* * *} p<.001$.

머니의 통제성 1 번 문항 꾸러미와 아버지의 통제성 1 번 문항 꾸러미의 오차 분산이 음수(헤이우드 케이스)로 나타나 이를 0.0005 로 고정한 후 분석을 다시 실시하였다. 측정모형의 적 합도는 $\mathrm{NFI}=.964, \mathrm{TLI}=.950, \mathrm{CFI}=.968, \mathrm{RMSEA}=.066$ 으로 양호하게 나타나 적합한 모형임을 확인하였다. 가구소득은 아 버지의 온정성 $(\beta=.07, \mathrm{p}<.01)$ 에 유의한 영향을 미쳤고, 어머 니의 취업여부 및 아동의 성별은 유의하지 않았다.

결혼만족도와 양육행동 간의 관계에서 우울감의 매개효과 검증을 실시하였다. 헤이우드 케이스로 나타난 어머니와 아버
지의 통제성 꾸러미의 오차분산 1 개씩을 매우 작은 수(0.0005) 로 고정하였다. 분석결과 모형의 적합도는 $\chi^{2}=1458.31, d f=$ $78, p<.001, \mathrm{NFI}=.915, \mathrm{TLI}=.887, \mathrm{CFI}=.921, \mathrm{RMSEA}=.084$ 로 나타났으며, 경로계수를 Figure 4와 Table 4에 제시하였다. 먼저 직접효과와 관련하여 자기효과의 경우 어머니의 결혼만 족도는 어머니와 아버지의 우울감 $(\beta=-.30 \sim-.39, p<.01$ 또는 $p$ <.001)을 부적으로 유의하게 예측했고, 어머니의 온정성, 통 제성을 정적으로 유의하게 예측하였다 $(\beta=.08 \sim .14, p<.01$ 또는 $p<.001)$. 아버지의 결혼만족도는 아버지의 우울감 $(\beta=$ 
-.31, $p$ <.001)과 부적으로 유의하게 예측하였고, 아버지의 온 정성과 통제성을 유의하게 예측하였다 $(\beta=.08 \sim .17, p<.01$ 또는 $p<.001)$. 다음으로 어머니의 우울감은 어머니의 온정성 $(\beta=-.25, p<.001)$ 을 아버지의 우울감은 아버지의 온정성 $(\beta=$ $-.19, p<.001)$ 을 유의하게 예측하였다. 또한 상대방효과의 직 접효과를 살펴보면 어머니의 결혼만족도는 아버지의 우울감 $(\beta=-.19, p<.001)$, 아버지의 통제성 $(\beta=.09, p<.01)$ 을 유의 하게 예측하고, 아버지의 결혼만족도는 어머니의 우울감 $(\beta=$ -.17, $p$ <.001)을 부적으로 유의하게 예측하였다.

Sobel Test를 활용한 매개효과를 Table 5에 제시하였다. 먼 저 결혼만족도가 온정성에 미치는 영향에서 우울감의 매개효 과에 대한 간접적 자기효과는 부모 모두자기효과/자기효과가 나타났다. 어머니의 결혼만족도가 어머니의 우울감을 거쳐 어 머니의 온정성에 영향을 미치는 자기효과/자기효과가(부분매 개) 나타났으며 $(\beta=.11, p<.001)$, 아버지의 결혼만족도가 아 버지의 우울감을 거쳐 아버지의 온정성에 영향을 미치는 자 기효과/자기효과가(부분매개) 나타났다 $(\beta=10, p<.001)$. 다 음으로 부모의 결혼만족도가 양육행동에 미치는 영향에서 우 울감의 매개효과에 대한 간접적 상대방효과는 부모 모두에게 상대방효과/자기효과(부분매개)가 나타났다. 어머니의 결혼 만족도가 아버지의 우울감을 거쳐 아버지의 온정성에 영향을 미치는 상대방/자기효과가(부분매개) 나타났으며( $\beta=.04, p$ <.001), 아버지의 결혼만족도가 어머니의 우울감을 거쳐 어머 니의 온정성에 영향을 미치는 상대방/자기효과가(부분매개) 나타났다 $(\beta=.10, p<.001)$.

\section{Discussion}

본 연구는 Belsky (1984)의 자녀양육과정 모델과 Cook과 Kenny (2005)의 자기-상대방 상호의존모델을 이론적 틀로 하여, 유아 기 자녀를 둔 부모의 결혼만족도가 양육행동에 미치는 영향에 서 행복감 및 우울감의 매개효과에서의 자기-상대방효과를 탐 색하였다. 연구결과를 요약하고 논의하면 다음과 같다.

\section{행복감의 매개효과에서의 자기-상대방효과}

부모의 결혼만족도가 양육행동에 미치는 영향에서 행복감의 매개효과와 관련하여 먼저, 부모의 결혼만족도와 행복감 간 의 경로에서 자기효과가 행복감과 온정성과 통제성 간의 경로 에서도 자기효과가 발견되었다. 이를 구체적으로 살펴보면,
어머니의 행복감은 결혼만족도가 온정성과 통제성에 미치는 영향을 완전매개하였으며 아버지의 행복감은 결혼만족도가 온정성에 미치는 영향을 부분매개 하였고, 통제성에 미치는 영향을 완전매개하였다. 이러한 결과는 부부관계가 어머니의 양육특성에 미치는 영향을 어머니의 심리적 특성이 완전매개 한다고 보고한 연구결과(Im, Choi, \& Choi, 2012)와 유사하며 어머니가 지각하는 남편의 지지도가 어머니의 합리적 지도, 애정적, 적극적인 양육참여에 미치는 영향에서 어머니의 심 리적 안녕감의 완전매개효과를 발견한 연구결과(S.-Y. Park \& $\operatorname{Rim}, 2002)$ 와도 유사하다. 또한 아버지의 안녕감이 아버지의 부부관계가 부모-자녀관계의 질에 미치는 영향을 부분매개한 연구(Shek, 2000)와도 유사한 맥락이다. 부모가 지각하는 행복 감이 결혼만족도와 온정성 및 통제성의 관계를 완전매개한 본 연구결과는 부모의 결혼만족도가 높다고 해서 반드시 부모가 온정적, 통제적 양육을 수행하기보다는 부모 스스로 부부관계 에 만족하고 결혼생활에 만족할수록 행복감을 느끼게 되고, 이러한 행복감이 높을 때 느끼는 긍정적 정서가 부모 자신의 온정적, 통제적 양육행동으로 연결됨을 나타낸다. 다시 말하 면, 부모의 결혼만족도와 행복감이 동시에 투입되었을 때, 부 모의 온정성 및 통제성을 예측하는 단일요인으로 결혼만족도 는 유의하지 않으며 이 과정에서 행복감이 연결통로가 된다는 것을 알 수 있다.

다음으로 간접적 상대방효과와 관련하여 부모의 결혼만족 도와 행복감 간의 경로에서는 상대방효과가 부모의 행복감과 배우자의 온정성 및 통제성 간의 경로에서는 자기효과가 나타 났다. 즉, 부모의 결혼만족도는 배우자의 행복감에 영향을 미 쳐 결혼만족도가 높을수록 배우자는 행복감을 더 많이 느끼 고, 배우자는 행복감을 더 많이 느낄수록 온정적, 통제적 양육 을 더 많이 수행하였다. 이는 부모의 결혼만족도가 어머니와 아버지의 온정성 및 통제성에 영향을 미치는 과정에서 부모가 결혼생활 및 부부관계에 대해 만족할 때 배우자의 행복감에 영향을 미치게 되고, 이는 배우자 자신의 높은 온정적, 통제적 양육행동으로 이어지게 됨을 의미한다. 이러한 결과는 아내가 지각하는 부부관계는 남편의 행복감에는 영향을 미치고, 남편 이 지각하는 부부관계는 아내의 행복감에는 영향을 미치지 않 음으로써 아내와 남편에게서 서로 다른 결과를 보고한 연구결 과(Joo, Jun, \& Wang, 2015)와는 불일치한다. 본 연구는 어머니 와 아버지의 결혼만족도, 행복감 및 양육행동 간의 관계에서 어머니와 아버지에게서 나타나는 양상이 서로 다르기보다는 부부관계 내에서 부부간에 상호 영향을 주고받으며 부모 모 두 서로의 행복감에 상대방의 영향을 받고, 자신이 느끼는 행 
복감은 부모 스스로의 온정적 및 통제적 양육행동으로 이어짐 을 확인하였다. 따라서 상호의존적인 부부관계 속에서 어머니 와 아버지가 온정성과 통제성이 높은 긍정적 양육을 수행하기 위해서는 스스로의 결혼만족도와 행복감을 높이기 위한 노력 을 기울여야 하며, 동시에 아내와 남편 모두 결혼만족도와 행 복감을 향상시키기 위한 노력이 함께 이루어져야 더 효과적일 수 있음을 알 수 있다.

\section{우울감의 매개효과에서의 자기-상대방효과}

부모의 결혼만족도가 양육행동에 미치는 영향에서 우울감의 매개효과와 관련하여 먼저, 어머니와 아버지의 결혼만족도 와 우울감 간의 경로와 어머니와 아버지의 우울감과 온정성 간의 경로에서 자기효과가 발견되었다. 이러한 결과는 부모 의 부부관계 및 부부갈등이 양육행동에 미치는 영향에서 어 머니와 아버지 모두에서 우울감의 매개효과가 나타난 연구 결과들(H.-S. Lee, 2017; Yeon, Yoon, \& Choi, 2016)과 유사하 다. 또한, 가정 내 가장 가까운 관계인 부부관계가 부모의 정서 에 영향을 미치게 되고 이러한 정서는 부모-자녀관계에서 부 모가 자녀를 대하는 태도에 영향을 미치게 된다는 전이(spillover)이론(Kouros et al., 2014)을 지지하는 결과이다. 부부는 가 정에서 많은 시간을 함께 하고 공유하는 동반자이므로 배우 자와의 관계는 서로의 정서에 많은 영향을 미칠 수 있으며(K. S. Park, 2013) 또한 우울감과 같은 부정적 정서는 부모-자녀와 같이 친밀한 관계 내에서 부정적 요인으로 작용하기 때문에 (Lovejoy, 1991) 부모가 우울감을 느끼는 경우에는 아동에게 강 압적 양육행동을 보인다거나 덜 민감한 양육을 하는 등의 부 정적 양육을 할 가능성이 높는 연구과 유사한 맥락이다(Cox, Puckering, Pound, \& Mill, 1987).

다음으로 간접적 상대방효과와 관련하여, 부모의 결혼만 족도와 우울감 간의 경로에서는 상대방효과가 부모의 우울감 과 부모의 온정성 간의 경로에서는 자기효과가 나타나 간접적 상대방 효과가 나타났다. 즉, 부모의 결혼만족도가 우울감에 미치는 상대방효과와 부모의 우울감이 자신의 온정성에 영향 을 미치는 자기효과가 발견되었으며 이러한 과정에서 우울감 은 부모 모두에게 완전매개효과가 나타났다. 즉, 부모의 결혼 만족도, 우울감, 온정성 간의 관계에서 부모의 온정성을 예측 하는 단일요인으로 부모의 결혼만족도는 유의하지 않으며 이 과정에서 부모 서로의 우울감이 연결통로가 된다는 것을 밝혔 다. 이러한 결과는 부모의 결혼만족도가 낮다고 해서 반드시 부모가 낮은 온정적 양육을 하기 보다는 부모가 부부관계에
불만족할 때 서로의 우울감을 높이게 되고, 높은 우울감은 각 자의 낮은 온정적 양육행동으로 이어지게 된다는 것이다. 이 는 부모가 지각하는 부부적응과 부부갈등이 부모 모두의 우울 감에 미치는 상대방효과가 나타난 연구결과(Beach et al., 2003) 와 부모의 우울감은 자신의 양육행동에 영향을 미치게 된다 는 연구결과들(Gelfand \& Teti, 1990; Lovejoy, 1991)과 유사한 맥락이다. 반면 부모의 결혼만족도, 우울감, 온정성 및 통제성 간의 관계에서 간접적 상대방효과가 통제성과 관련해서는 부 모 모두에게 발견되지 않았다. 즉, 부모의 결혼만족도와 우울 감은 양육행동의 두 가지 요인 가운데 통제성보다는 온정성에 더 중요한 영향을 미치게 됨을 확인하였다. 이는 부모가 우울 감과 같은 부정적 정서를 느끼고 있을 때에는 양육스트레스가 증가하며 양육에 대한 심리적 부담감이 증가하므로(J. Kim, 2017), 아이와의 친밀한 시간을 갖거나 함께 놀아주고, 아이 의 행동이나 성취에 대해 관심을 가지는 등의 온정적 양육행 동을 하기 어렵기 때문으로 볼 수 있으나 반면 아동을 훈육하 고, 규칙을 지키도록 하는 등의 통제적 양육행동은 온정성에 비해 부모의 우울감과는 관련이 낮은 것으로 볼 수 있다. 따라 서 서로 의존적인 부부관계 내에서 부모가 온정성이 높은 긍 정적 양육행동을 수행하기 위해서는 부모가 스스로의 결혼만 족도를 높이고, 우울감을 낮추기 위해 노력함과 동시에 배우 자의 결혼만족도와 우울감 정도를 파악하여 결혼만족도를 높 이고, 우울감을 낮출 수 있도록 함께 돕는 것이 더욱 효과적일 수 있음을 의미한다.

본 연구의 제한점과 함께 후속연구를 위한 제언을 하면 다 음과 같다. 첫째, 본 연구는 양육행동에 대한 보고를 부모의 자 기보고로만 측정함으로써 개인의 주관적인 평가에만 의존하 였다. 양육에 대한 연구에서는 자기보고 이외에도 일상적인 상호작용 상황 속에서 제 3 자에 의한 측정과 같은 객관적인 평 가방법이나 심층 면접을 통해 보다 정확한 정보를 얻을 수 있 으므로 후속 연구에서는 보다 다양한 평가방법을 통한 연구방 법의 필요성이 요구된다. 둘째, 본 연구는 자기-상대방효과를 횡단적 접근에만 기초하여 살펴보았다. 부모의 결혼만족도, 행복감 및 우울감, 양육행동의 관계에 대한 횡단적 자기-상대 방효과를 살펴보았으나, 각 변인 간의 인과적 관계에 대한 폭 넓은 이해를 위해서는 종단적 접근으로 살펴볼 필요가 있다. 추후 연구에서는 종단적 접근에 기초한 자기-상대방효과를 살펴보는 것이 바람직할 것이다.

이러한 제한점에도 불구하고 본 연구는 다음과 같은 학문 적.실용적 의의가 있다. 첫째, 부모의 결혼만족도, 행복감 및 우울감, 양육행동 간의 관계에서 자기-상대방효과 검증을 통 
해 부모 서로 간의 영향력을 검증했다는 의의가 있다. 양육행 동에 대한 연구에서 부모의 자기효과와 상대방효과를 구체적 으로 분석하는 일은 어머니와 아버지 각각의 특성에 따른 차 별화된 지원이 가능함을 시사한다. 따라서 부모의 긍정적 양 육행동에 영향을 미치는 요인들의 영향력에 대한 정확한 연구 결과를 위해 부모의 의존성 및 역동성을 파악할 필요할 수 있 는 APIM을 활용한 측정방법을 활용할 필요가 있음을 재확인 하였다는 의의를 가진다. 둘째, 행복감과 우울감과 같은 심리 적 특성이 방향의 차이는 있으나 독립적 특성을 가짐을 확인 하였다. 이는 우울감과 같은 부정적 심리적 특성을 제거하는 방법만으로 행복감을 증진시키기에는 어려움이 있다고 주장 한 Seligman (2002)의 주장을 지지한다. 따라서 부모의 긍정적 양육행동을 위하여 우울감과 같은 부정적 정서를 낮추고 감 소시키는 데 초점을 두기 보다는 부정적 정서를 낮춤과 동시 에 행복감과 같은 긍정적 정서를 높일 수 있도록 돕는 것이 더 욱 효과적일 수 있음을 밝혔다는 데 의의가 있다. 셋째, 부모의 긍정적 양육행동의 하위 범주인 온정적 및 통제적 양육행동이 서로 독립적 구성 개념일 수 있음을 확인하였다. 지금까지 많 은 연구들에서 양육행동의 범주를 다양한 방법으로 하나의 측 정변인으로 범주화하여 사용하기도 했는데, 본 연구에서 밝혀 진 바와 같이 양육행동 각각의 하위 척도들은 서로 독립적 구 성 개념일 수 있다. 따라서 본 연구는 양육행동 차원을 각각의 독립된 차원으로 좀 더 세분화, 구체화하여 분석할 필요가 있 음을 밝혀냈다는 것에 의의가 있다. 본 연구의 결과는 부모의 긍정적 양육행동을 위하여, 부모의 결혼만족도와 행복감을 높 이고, 우울감을 낮추기 위한 부모 스스로의 노력 뿐 아니라 부 부의 서로 간 노력이 함께 필요함을 환기시켰다. 본 연구는 유 아기 부모를 위한 부모 상담과 부모-자녀관계 증진을 위한 프 로그램 개발을 위한 기초 자료로 활용될 수 있을 것이다.

\section{Acknowledgements}

This work was supported by the Ministry of Education of the Republic of Korea and the National Research Foundation of Korea (NRF-2016S1A3A2924375).

\section{Notes}

This article is a part of the first author's Doctor's thesis submitted in 2019, and was presented as a poster at the 2019 Annual Spring
Conference of the Korean Association of Child Studies.

\section{Conflict of Interest}

No potential conflict of interest relevant to this article was reported.

\section{References}

\section{In English}

Anderson, J. C., \& Gerbing, D. W. (1988). Structural equation modeling in practice: A review and recommended two-step approach. Psychological Bulletin, 103(3), 411-423. doi:10.1037/00332909.103.3.411

Argyle, M. (2001). The psychology of happiness (2nd ed.). London: Routledge.

Bandalos, D. L. (2002). The effects of item parceling on goodnessof-fit and parameter estimate bias in structural equation modeling. Structural Equation Modeling: A Multidisciplinary Journal, 9(1), 78-102. doi:10.1207/S15328007SEM0901_5

Baumgardener, S. R. \& Crothers, M. K. (2009). Positive psychology. Upper Saddle River, NJ: Prentice Hall.

Beach, S. R. H., Katz, J., Kim, S., \& Brody, G. H. (2003). Prospective effects of marital satisfaction on depressive symptoms in established marriages: A dyadic model. Journal of Social and Personal Relationships, 20(3), 355-371. doi:10.1177/0265407503020003005

Belsky, J. (1984). The determinants of parenting: A process model. Child Development, 55(1), 83-96. doi:10.2307/1129836

Bentler, P. M. (1990). Comparative fit indexes in structural models. Psychological Bulletin, 107(2), 238-246. doi:10.1037/00332909.107.2.238

Bentler, P. M., \& Bonett, D. G. (1980). Significance tests and goodness of fit in the analysis of covariance structures. Psychological bulletin, 88(3), 588-606. doi:10.1037/00332909.88.3.588

Browne, M. W., \& Cudeck, R. (1993). Alternative ways of assessing model fit. In K. A. Bollen \& J. S. Long (Eds.), Testing structural equation models (pp. 136-162). Newbury Park, CA: Sage.

Cheng, H., \& Furnham, A. (2003). Personality, self-esteem, and demographic predictions of happiness and depression. Personality and Individual Differences, 34(6), 921-942. doi:10.1016/S0191-8869(02)00078-8

Chung, H. (2004). Application and revision of the Kansas Marital 
Satisfaction Scale for use of Korean couples. Psychological Reports, 95(3), 1015-1022. doi:10.2466/pr0.95.3.10151022

Compton, W. C. (2005). An introduction to positive psychology. Belmont, CA: Thomson Wadsworth.

Cook, W. L., \& Kenny, D. A. (2005). The actor-partner interdependence model: A model of bidirectional effects in developmental studies. International Journal of Behavioral Development, 29(2), 101-109. doi:10.1080/016502504 44000405

Cox, A. D., Puckering, C., Pound, A., \& Mills, M. (1987). The impact of maternal depression in young children. Journal of Child Psychology and Psychiatry, 28(6), 917-928. doi:10.1111/j.1469-7610.1987.tb00679.x

Davis, R. N., Davis, M. M., Freed, G. L., \& Clark, S. J. (2011). Fathers' depression related to positive and negative parenting behaviors with 1-year-old children. Pediatrics. 127(4). 612618. doi:10.1542/peds.2010-1779

Diener, E., Emmons, R. A., Larsen, R. J., \& Griffin, S. (1985). The Satisfaction with Life Scale. Journal of Personality Assessment, 49(1), 71-75. doi:10.1207/s15327752jpa4901_13

Duncan, G. J., Books-Gunn, J., \& Klebanov, P. K. (1994). Economic deprivation and early-childhood development. Child Development, 65(2), 296-318. doi:10.2307/1131385

Edhborg, M., Lundh, W., Semiyr, L., \& Widstrom, A. M. (2003). The parent-child relationship in the context of marital depressive mood. Archives of Woman's Mental Health, 6, 211-216. doi:10.1007/s00737-003-0020-x

Fishman, E. A., \& Meyers, A. S. (2000). Marital satisfaction and child adjustment: Direct and mediated pathways. Contemporary Family Therapy 22, 437-452. doi:10.1023/ A: 1007848901640

Gelfand, D. M., \& Teti, D. M. (1990). The effects of maternal depression on children. Clinical Psychology Review, 10(3), 329-353. doi:10.1016/0272-7358(90)90065-I

Goodman, J. H. (2008). Influences of maternal postpartum depression on fathers and on father-infant interaction. Infant Mental Health Journal, 29(6), 624-643. doi:10.1002/ imhj.20199

Greenberger, E., Goldberg, W. A., Hamill, S., O’Neil, R., \& Payne, C. K. (1989). Contributions of a supportive work environment to parents' well-being and orientation to work. American Journal of Community Psychology, 17(6), 755-783. doi:10.1007/BF00922737

Hossian, Z., Field, T. M., Gonzales, J., Malphurs, J., Del valle, C., \& Pickens, J. (1994). Infants of "depressed" mothers interact better with their nondepressed fathers. Infant Mental health Journal, 15(4), 348-357. doi:10.1002/10970355(199424)15:4<348::AID-IMHJ2280150404>3.0.CO;2-Y

Kenny, D. A. (1996). Models of non-independence in dyadic research. Journal of Social and Personal Relationships, 13(2), 279-294. doi:10.1177/0265407596132007

Kessler, R. C., Andrew, G., Colpe, L. J., Hiripi, E., Mroczek, D. K., Normand, S.-L. T., Zaslavsky, A. M. (2002). Short screening scales to monitor population prevalences and trends in non-specific psychological distress. Psychological Medicine, 32(6), 959-976. doi:10.1017/ s0033291702006074

Kline, R. B. (2015). Principles and practice of structural equation modeling (4th ed.). New York: The Guilford Press.

Kouros, C. D., Papp, L. M., Goeke-Morey, M. C. \& Cummings, E. M. (2014). Spillover between marital quality and parentchild relationship quality: Parental depressive symptoms as moderators. Journal of Family Psychology, 28(3), 315-325. doi: $10.1037 / \mathrm{a} 0036804$

Krishnakumar, A., \& Buehler, C. (2000). Interparental conflict and parenting behaviors: A meta analytic review. Family Relations: An Interdisciplinary Journal of Applied Family Studies, 49(1), 25-44.

Little, T. D., Rhemtulla, M., Gibson, K., \& Schoemann, A. M. (2013). Why the items versus parcels controversy needn't be one. Psychological methods, 18(3), 285-300. doi:10.1037/ a0033266

Lovejoy, M. C. (1991). Maternal depression: Effects on social cognition and behavior in parent-child interactions. Journal of Abnormal Child Psychology, 19(6), 693-706. doi:10.1007/ BF00918907

Lyubomirsky, S., \& Lepper, H. S. (1999). A measure of subjective happiness: Preliminary reliability and construct validation. Social Indicators Research, 46, 137-155. doi:10.1023/ A: 1006824100041

Markman, H, J., Stanley, S. M., \& Bluranberg, S. L. (2001). Fighting for your marriage: Positive steps for preventing divorce and preserving a lasting love (1st ed.). San Francisco, CA: Jossey-Bass Publishers.

Muraru, I. D., \& Turlluc, M. N. (2015). Similarity, communication, and satisfaction in intimate relationships: The role of ideal standards. Psihologia Socială, 35(1), 109122.

Peterson, C. (2006). A primer in positive psychology. New York: Oxford University Press.

Peterson, C., \& Steen, T. A. (2002). Optimistic explanatory style. In C. R. Snyder \& S. J. Lopez (Eds.), Handbook of positive psychology (pp. 244-256). New York: Oxford University Press.

Ponnet, K., Wouters, E., Mortelmans, D., Pasteels, I., De Backer, C., Van Leeuwen, K., \& Van Hiel, A. (2013). The influence of mothers' and fathers' parenting stress and depressive symptoms on own and partner's parent-child communication. Family Process, 52(2), 312-324. doi:10.1111/famp.12001 
Russell, D. W., Kahn, J. H., Spoth, R., \& Altmaier, E. M. (1998). Analyzing data from experimental studies: A latent variable structural equation modeling approach. Journal of Counseling Psychology, 45(1), 18-29. doi:.1037/00220167.45.1.18

Schumm, W. A., Nichols, C. W., Schectman, K. L., \& Grigsby, C. C. (1983). Characteristics of responses to the Kansas Marital Satisfaction Scale by a sample of 84 married mothers. Psychological Reports, 53(2), 567-572. doi:10.2466/ pr0.1983.53.2.567

Seligman, M. E. P. (2002). Authentic happiness : Using the new positive psychology to realize your potential for lasting fulfilment. New York: Free Press.

Seligman, M. E. P., \& Csikszentmihalyi, M. (2000). Positive psychology: An introduction. American Psychologist, 55(1), 5-14. doi:10.1037/0003-066X.55.1.5

Shek, D. T. L. (2000). Parental marital quality and well-being, parent-child relational quality, and chinese adolescent adjustment. The American Journal of Family Therapy, 28(2), 147-162. doi:10.1080/019261800261725

White, C., \& Barrowclough, C. (1998). Depressed and non-depressed mothers with problematic preschoolers: Attributions for child behaviors. British Journal of Clinical Psychology, 37(4), 385398. doi:10.1111/j.2044-8260.1998.tb01396.x

Wilson, S., \& Durbin, C. E. (2010). Effects of paternal depression on fathers_parenting behaviors: A meta-analytic review. Clinical Psychology Review, 30, 167-180. doi:10.1016/ j.cpr.2009.10.007

\section{In Korean}

Chae, Y., M. \& Kwak, S. J. (2017). The efects of fathers' marital satisfaction and parenting behaviors on preschoolers' externalizing problem behaviors. Journal of the Korean Society for Wellness, 12(1), 1-13. doi:10.21097/ksw.2017. 02.12.1.1

Cho, B., Lee, J., Lee, H., \& Kwon, H. (1999). Dimensions and assessment of Korean parenting style. Journal of The Korean Home Economics Association, 37(10), 123-133.

Choi, H.-S. \& Yeon, E.-M. (2014). Actor and partner effect of infant-parents' psychological characteristics, parenting stress, and positive parenting attitude. Early Childhood Education Research \& Review, 18(6), 5-30.

Choi, Y. K., Bae, Y. J., Song, S. Y., Lim, J. B., Lee, Y. J., Kim, S. A., \& Kim, S. K. (2014). The panel study on korean children 2014 (Report No. 2014-33). Seoul: Korean Institute of Chid Care and Education.

Han, I. S., \& Yang, H. C. (2015). Longitudinal relationship between marital conflict and parenting behavior and problem behavior in early childhood. Korean Journal of
Christian Counseling, 26(3), 287-317.

Han, J. H., \& Hong, G. O., (2000). Mother's self-perception and parenting behaviors-Mothers for kindergarten children-. Journal of Future Early Childhood Education, 7(1), 85-111.

Im, H. J., Choi, H. J., \& Choi, S. N. (2012). The effect of father's participation in child-care, parental characteristics, and mother's psychological characteristics on mother's parenting characteristics. Journal of Future Early Childhood Education, 19(2), 83-106.

Joo, S., Jun, H, J., \& Wang, S. K. (2015). The mediating role of marital relationship in the association between differentiation of self and happiness: Focusing on actor effects and partner effects. Journal of Family Relations, 20(3), 113-132.

Kang, H., \& Park, H. (2013). The development of infants from low-income families, parenting characteristics, and daily routines. Family and Environment Research, 51(6), 613-622. doi:10.6115/fer.2013.51.6.613

Kim, C.-K., \& Cho, M.-K. (2015). Affect of mother s adult attachment, marital satisfaction and nurturing attitude on individuation \& externalization problem in young children. Journal of Learner-Centered Subject Education Research, 15(6), 171-195.

Kim, H.-N., \& Lee, M.-S. (2013). The influence of mother's depression \& maritalon the problem behavior of their children: maternal parenting behaviorsas a mediator. Asian Journal of Child Welfare and Development, 11(3), 73-92.

Kim, H.-W., \& You, S.-K. (2017). Emotion regulation and marital dissatisfaction as mediating factors in relationship between parental adult attachment and parenting behaviors. The Korean Journal of Counseling and Psychotherapy, 29(1), 199226.

Kim, J. (2017). The influences of paternal depression, self-esteem, and parenting stress on child's self-control: with mediation of warm parental behavior. Korean Journal of Chid Care and Education Policy, 11(1), 29-49.

Korea Institute of Child Care and Education. (2014). Panel study of Korean children $7^{\text {th }}$ survey [Data file and codebook]. Retrieved from KICCE website: https://panel.kicce.re.kr/

Kwon, S. (2008). Positive Psychology: Haengbog-ui gwahagjeog tamgu [행복의 과학적 탐구]. Seoul: Hakjisa.

Lee, H. O., \& Kim, Y. H. (2016). Effects of mother's personality, marital relationship, and relationship with young children on happiness. Journal of Early Childhood Education \& Educare Welfare, 20(3), 161-188.

Lee, H.-S. (2017). The mediating effects of depression in the relationships between marital conflict and parenting behavior of young children's fathers. Journal of Convergence for Information Technology, 7(6), 237-244. doi:10.22156/ CS4SMB.2017.7.6.237

Lee, J. Y., \& Jang, M. K. (2009). Relationship between maternal 
depression and parenting behaviors: The mediating effects of irrational beliefs in parenting. Cognitive Behavior Therapy in Korea, 9(2), 1-16.

Lee, J. R., Kim, G. S., Song, S. Y., Yi, Y. J., Kim, J. M., Kim, S. A., $\&$ Kim, S. K. (2015). Panel study on Korean children (PSKC) 2015 (Report No. 2015-33). Seoul: Korean Institute of Chid Care and Education.

Lee, K.-Y. (2002). Ego-identity of school-aged children: Effects of level of income and perceived parental behaviors. Journal of the Korean Home Economics Association, 40(10), 65-76.

Lee, Y.-R., \& Park, S.-Y. (2009). The effects of family climate of fathers' family of origin, marital and life satisfaction, and parenting on father-son intimacy. Journal of Korean Home Management Association, 27(4), 177-188.

Lee, Y.-S. (2017). Impact of perceived propensities for depression and anxiety on maternal style in mothers with children in early childhood. Korean Journal of Local Government \& Administration Studies, 31(4), 309-335. doi:10.18398/ kjlgas.2017.31.4.309

Park, H. K., \& Youn, G. J. (2012). The effects of the mother-child relationship and marital satisfaction on the subjective wellbeing of mothers with young children. Korean Journal of Child Study, 33(2), 243-261. doi: https://doi.org/10.5723/ KJCS.2012.33.2.243

Park, K. S. (2013). The relationships of marital conflicts, developmental level of object relations and depressiveness. The Korean Journal of Stress Research, 21(4), 293-302.

Park, S.-Y., \& Rim, M.-R. (2002). Working mother's parenting behavior as related to job characteristics, day care quality, and psychological well-being. Journal of Korean Home
Management Association, 20(2), 57-68.

Seo, Y. S. (2010). Testing mediator and moderator effects in counseling psychology research: Conceptual distinction and statistical considerations. The Korean Journal of Counseling and Psychotherapy, 22(4), 1147-1168.

Yeon, E.-M., \& Choi, H.-S. (2014). Relationships among psychological characteristics of infant-father, parenting engagement and attitude, and young children's interactive peer play. Journal of Early Childhood Education \& Educare Welfare, 18(4), 229-251.

Yeon, E.-M., Yoon, H.-O., \& Choi, H.-S. (2016). Moderating effects of family incomes on the relationship among marital conflict, depression, and parenting attitude: The actorpartner interdependence model. The Journal of Korea Open Association for Early Childhood Education, 21(2), 1-28.

Yoo, M. S. (2016). Factors associated with children's subjective wellbeing (Doctoral dissertation). Retrieved from http://s-space. snu.ac.kr/bitstream/10371/120466/1/000000133881.pdf

\section{ORCID}

Ju yeong Bae https://orcid.org/0000-0002-2233-7208

Hyun-sim Doh https://orcid.org/0000-0002-7393-4520

Received February 29, 2020

Revision received April 25, 2020

Accepted May 24, 2020 